\title{
Effects of maturity on nutritive value of field-cured hays from common vetch and hairy vetch
}

\author{
Madiha HAJ AYED ${ }^{\mathrm{a} *}$, Javier GonZÁLEZ ${ }^{\mathrm{a} * *}$, Rafael CABALLERO $^{\mathrm{b}}$, \\ María ReMEdios AlviR ${ }^{\mathrm{a}}$ \\ a Departamento de Producción Animal, ETS de Ingenieros Agrónomos, \\ Ciudad Universitaria, 28040 Madrid, Spain \\ ${ }^{\mathrm{b}}$ Finca Experimental La Poveda, CCMA, CSIC, Ctra de Campo Real km 1.300, \\ 28500 Arganda del Rey, Madrid, Spain
}

(Received 6 March 2000; accepted 7 November 2000)

\begin{abstract}
Hay samples from common vetch and hairy vetch were collected at three maturity stages (bloom and two stages during pod-filling) with the aims of assessing the optimum harvesting stage and comparing the nutritive value of the two species. As maturation progressed, the hay content in cell wall increased and that of CP decreased. The two species showed different patterns in line with the maturing process, regarding digestibility of nutrients and effective degradability of DM and CP. Common vetch hay showed a progressive decrease of digestibility and degradability values in line with the maturing process of vegetative structures. Hairy vetch hay, however, showed a compensatory effect produced by an increasing grain proportion at later maturity stages. The nutritive value at flowering was higher for common vetch hay than for hairy vetch hay, but the opposite was observed at the stage of mature legumes. Voluntary DM intake was not affected by the species or harvest stages. Degradation studies, carried out by the nylon bag technique, showed that in these hays $\mathrm{CP}$ was extensively rumen degraded. Consequently, their digestible bypass protein should be low.
\end{abstract}

common vetch hay / hairy vetch hay / digestibility / maturity / rumen degradability

Résumé - Effets du stade de maturité sur la valeur nutritive des foins de vesce commune et de vesce velue. Une étude comparative sur la qualité des foins de vesce commune et de vesce velue, recoltés à trois stades de végétation (floraison et deux stades pendant la formation des gousses) a été conduite avec le but d'établir le stade optimal de coupe et de comparer la valeur nutritive des deux espèces. Au cours de la maturation des légumes, la teneur en parois cellulaires des foins a augmenté et celle des MAT a diminué pour les deux espèces, mais les évolutions de la digestibilité des différents constituants et de la dégradabilité de la MS et des MAT ont été différentes. La digestibilité et la dégradabilité du foin de vesce commune ont diminué progressivement avec la maturation des

* Present address: École Supérieure d'Agriculture de Mateur, 7030 Mateur, Tunisia.

** Correspondence and reprints

Tel.: (34) 91 5493069; fax: (34) 91 5499763; e-mail: jgonzalez @ pan.etsia.upm.es 
structures végétatives. En revanche, pour le foin de vesce velue on a observé un effet compensatoire à la maturité du grain dû à l'augmentation de la proportion de grains. La valeur nutritive à la floraison est supérieure pour le foin de vesce commune, mais l'opposé est observé à la maturité du grain. La quantité de foin volontairement ingérée n'a pas été affectée par l'espèce ou le stade de végétation. Des études de dégradation avec sachets de nylon ont montré que la dégradabilité des MAT de ces foins est très elevée et que leur teneur en protéine non degradée digestible dans l'intestin doit être faible.

foin de vesce commune / foin de vesce velue / stade de végétation / digestibilité / dégradabilité ruminale

\section{INTRODUCTION}

Common vetch (Vicia sativa L.) and hairy vetch (Vicia villosa Roth) are annual legume species, which are generally cultivated in rotation with winter cereals in the Mediterranean basin. They are mainly used for haymaking. Common vetch is currently dominant, since it shows a higher leaf to stem ratio than hairy vetch at the bloom stage and, consequently, a higher $\mathrm{CP}$ concentration [21]. Nevertheless, hairy vetch planting is not disregarded since it can produce higher yield than common vetch in years of late spring rainfall [6].

For temperate and perennial legumes such as lucerne (Medicago sativa L.) and some clovers (Trifolium spp.), forage biomass and forage quality are often negatively correlated. This offsetting effect is reached near the bloom stage, which is recommended as optimum for maximizing the export of nutrients [5, 19]. In Vicia spp. and other annual legumes such as soya bean (Glycina max (L.) Merr.), the seed fraction accounts for a greater proportion of the harvested biomass, and thus moving the harvest stage to the pod filling period may be desirable $[8,12]$. For this reason, comparative forage quality studies of these annual legumes should include harvesting stages within the seed filling period.

Data on voluntary intake and digestibility of vetch hays are scarce, and most upto-date work has been focused on fresh forages, either of common vetch $[2,10,22]$ or of hairy vetch $[13,15]$. Otherwise, late data compiled on the quality of Mediterranean forage resources, do not report animal response of vetch hays [1].

The main objective of this study was then to test how moving the harvesting stage beyond bloom would affect nutrient concentration and digestive utilization in hays from common vetch and hairy vetch forages under similar cropping and haymaking conditions.

\section{MATERIALS AND METHODS}

\subsection{Hays studied}

Common vetch (var. "Comun Tolerada") and hairy vetch (var. "Glabrescens") were planted at the La Poveda Field Station (30 km Southeast of Madrid, Spain) at seeding rates of 80 and $50 \mathrm{~kg} \cdot \mathrm{ha}^{-1}$, respectively, and were grown under the rainy continental Mediterranean climatic conditions of the Castilian Plain. The main effect within forage species was the harvesting stage. The three levels $\left(\mathrm{L}_{1}, \mathrm{~L}_{2}\right.$ and $\left.\mathrm{L}_{3}\right)$ were, respectively, flowering (at least $50 \%$ of plants) and two seed maturing stages defined by progressively higher DM concentration of the seed (25-30\% and $60-70 \%$ of DM). Farm cultivation and haymaking practices of vetch hays in the southern Castilian Plain have been reported elsewhere [9].

Treatments $(2$ species $\times 3$ harvesting stages) were distributed in a completely 
randomized design with three replicates in plots of $4 \mathrm{~m} \times 50 \mathrm{~m}$. At each harvest, two bales were randomly selected from each replicated plot, and the six bales (some $125 \mathrm{~kg}$ hay) were pooled representing the sample of each treatment. In addition, in order to assess the effect of baling on nutrient concentrations, a $1.5 \mathrm{~kg}$ sample was collected from the swathes just before pressing for botanical and chemical analysis. Also, the leaf to stem ratio at the flowering stage and the harvest index (ratio of grain dry weight to total aerial biomass) at seed filling stages were determined in ten randomly selected plants of each species. Sample characteristics and climatic conditions during haymaking are shown in Table I.

\subsection{Voluntary intake and digestibility}

Two groups of three wethers (mean live weight: $70 \mathrm{~kg}$ ) of the Manchega breed were used. The animals were housed during the months of May and June in digestibility cages with free access to water and a vitamin-mineral block. Vetch hays were offered to animals in chopped form. Animals were fed ad libitum (5-10\% refusal) in two meals per day at 09.00 and $17.00 \mathrm{~h}$. Each lot of sheep was randomly assigned to each forage species and the sequence of experimental samples was randomly established for both groups as $\mathrm{L}_{1}, \mathrm{~L}_{2}$ and $\mathrm{L}_{3}$. Feeding periods lasted approximately 19 days divided into the following phases: phase 1 (9 days) adaptation to the hay diet and stable intake; phase 2 (10 days) - intake measurement; and phase 3 (last 7 days of the previous phase) - nutrient digestibility measurement. In this last phase, daily samples of the forage on offer $(100 \mathrm{~g})$, refused (10\% of weight) and from the faeces (10\% of weight) were collected.

\subsection{Rumen degradation of DM and $\mathrm{CP}$}

Rumen degradation was determined on three wethers with 55-62 kg live weight of the Manchega breed, provided with a ruminal cannulae and fed with a $2: 1$ vetch-oat hay to concentrate diet. This diet contained $140 \mathrm{~g} \mathrm{CP} \cdot \mathrm{kg}^{-1} \mathrm{DM}$ and $380 \mathrm{~g} \mathrm{NDF} \cdot \mathrm{kg}^{-1} \mathrm{DM}$ and was distributed at $40 \mathrm{~g} \mathrm{DM} \cdot \mathrm{kg}^{-0.75}$ in two equal meals at 09.00 and $17.00 \mathrm{~h}$.

Nylon thermally-sealed bags (ref. $120 \mathrm{~T}$, Tissages Tissues Techniques, Villeneuve La Garenne, France) of $7 \mathrm{~cm}$ by $11 \mathrm{~cm}$ (inner

Table I. Main characteristics of experimental forage samples.

\begin{tabular}{|c|c|c|c|c|c|c|}
\hline \multirow[t]{2}{*}{ Item } & \multicolumn{3}{|c|}{ Common vetch } & \multicolumn{3}{|c|}{ Hairy vetch } \\
\hline & $\mathrm{L}_{1}{ }^{1}$ & $\mathrm{~L}_{2}$ & $\mathrm{~L}_{3}$ & $\mathrm{~L}_{1}$ & $\mathrm{~L}_{2}$ & $\mathrm{~L}_{3}$ \\
\hline Haymaking period & $6-5 / 14-5$ & $28-5 / 4-6$ & $11-6 / 15-6$ & $28-5 / 4-6$ & $22-6 / 28-6$ & $5-7 / 7-7$ \\
\hline $\mathrm{T} \max ^{2}\left({ }^{\circ} \mathrm{C}\right)$ & 22.5 & 25.7 & 27.0 & 26.5 & 31.5 & 33.2 \\
\hline $\mathrm{T} \min ^{2}\left({ }^{\circ} \mathrm{C}\right)$ & 9.4 & 10.9 & 10.8 & 11.1 & 16.5 & 14.8 \\
\hline Seed DM $\left(\mathrm{g} \cdot \mathrm{kg}^{-1}\right)$ & - & 250 & 600 & - & 300 & 700 \\
\hline Grain weight (mg per seed) & - & 13 & 47 & - & 19 & 31 \\
\hline Harvest index ${ }^{3}$ & - & 0.10 & 0.40 & - & 0.15 & 0.27 \\
\hline Leaf to stem ratio 4 & 1.6 & - & - & 1.3 & - & - \\
\hline
\end{tabular}

${ }^{1} \mathrm{~L}_{1}, \mathrm{~L}_{2}$, and $\mathrm{L}_{3}$ are harvesting stages from flowering $\left(\mathrm{L}_{1}\right)$ to progressively higher DM concentration of the seed during the seed filling period $\left(\mathrm{L}_{2}\right.$ and $\left.\mathrm{L}_{3}\right)$.

${ }^{2}$ Maximum and minimum air temperatures during the haymaking period.

${ }^{3}$ Ratio of grain to whole aboveground biomass.

${ }^{4}$ Whole forage DM concentration at flowering was 16 and $18 \%$ in common vetch and hairy vetch. 
dimensions) and $46 \mu \mathrm{m}$ of pore size were used. Hay samples were ground through a $2 \mathrm{~mm}$ sieve and approximately $3 \mathrm{~g}$ (air dry basis) was weighed into each bag. Two series of 12 bags which encompassed an associated pair of hay samples at the same harvesting stage were incubated in the rumen. The bags were introduced just after the $09.00 \mathrm{~h}$ meal and removed at 3, 6, 12, 24, 48 and $72 \mathrm{~h}$. After incubation, bags were washed in cold water, and frozen at $-20^{\circ} \mathrm{C}$. Thawed samples were washed three times for $5 \mathrm{~min}$ in a turbine machine and subsequently dried at $80{ }^{\circ} \mathrm{C}$ for $48 \mathrm{~h}$. Three additional bags of each hay were reserved for the zero incubation that involved the washing procedure without prior rumen incubation. For each animal, disappearance data of DM and CP was fitted to the model proposed by Ørskov and McDonald [14]. We estimated the effective degradability (D) of $\mathrm{DM}$ and $\mathrm{CP}$ in each sheep using its rumen particulate outflow rate $\left(k_{p}\right)$ as these authors did. These values were determined for the vetch-oat hay included in the diet. A description of the method and results (mean value $=2.91 \pm 0.32 \% \cdot \mathrm{h}^{-1}$ ) has been previously reported [13].

\subsection{Chemical analysis}

Dry matter, organic matter (OM), and nitrogen of hays, refusals, and feces were determined following AOAC procedures [4]. Crude protein was estimated by multiplying Kjeldahl N by 6.25 . Neutral-detergent fibre (NDF), acid detergent fibre (ADF), and acid-detergent lignin (ADL) were measured as described by Robertson and Van Soest [16]. Acid-detergent insoluble N (ADIN) was determined by Kjeldahl analysis of the direct ADF residues. Gross energy (GE) and energy digestibility of the baled hays were determined by measuring heat production from the offered hays, refusals and feces in an adiabatic calorimeter bomb.

\subsection{Statistical analyses}

Data of digestibility and voluntary intake were subjected to two different variance analyses. In the first one, the effects allocated to the harvesting stage $(\mathrm{H})$ and to the animals (A) were examined for each hay $(y=\mu+H+A+\varepsilon)$, and the means were compared by the least significant difference procedure with a 0.05 probability level. In the second analysis, the species effect (S) within harvesting stages was examined $(y=\mu+S+\varepsilon)$. Degradation kinetics were fitted by non-linear regression. Kinetic parameters and degradability values were examined as described above, but in this case, animals were considered as blocks for both types of variance analysis. All analyses were performed using the SAS v 6.08 statistical program [20].

\section{RESULTS}

\subsection{Chemical composition of vetch hays}

Botanical characterization (Tab. I) shows a lower leaf to stem ratio at flowering and a higher DM seed content in hairy vetch than in common vetch. Differences for seed weight and harvest index were mainly important at $\mathrm{L}_{3}$, with lowest values for hairy vetch.

Table II shows the chemical composition of common vetch and hairy vetch hays prior to and after baling. For unbaled hays of both species, the OM content remained fairly constant among harvesting stages. On the contrary, $\mathrm{CP}$ concentration decreased in the $\mathrm{L}_{1}-\mathrm{L}_{2}$ phase but remained unchanged in the $\mathrm{L}_{2}-\mathrm{L}_{3}$ phase, and NDF concentration increased over the seed filling period. Nevertheless, the rates of change of $\mathrm{CP}$ and NDF were lower for hairy vetch hay than for common vetch hay $\left(1.52\right.$ vs. $1.86 \mathrm{~g} \mathrm{CP} \cdot \mathrm{d}^{-1}$ and 2.58 vs. $2.89 \mathrm{~g} \mathrm{NDF} \cdot \mathrm{d}^{-1}$, for the whole $\mathrm{L}_{1}-\mathrm{L}_{3}$ period). ADL content of both hays was fairly constant. Figure 1 shows the main chemical components (CP, NDF, and ADL) 
Table II. Chemical composition $\left(\mathrm{g} \cdot \mathrm{kg}^{-1} \mathrm{DM}\right)$ and energy concentration $\left(\mathrm{MJ} \cdot \mathrm{kg}^{-1} \mathrm{DM}\right)$ of field-cured hays from common vetch and hairy vetch at three harvest stages prior to and after baling.

\begin{tabular}{|c|c|c|c|c|c|c|}
\hline \multirow[b]{2}{*}{ Item } & \multicolumn{3}{|c|}{ Common vetch } & \multicolumn{3}{|c|}{ Hairy vetch } \\
\hline & $\mathrm{L}_{1}^{1}$ & $\mathrm{~L}_{2}$ & $\mathrm{~L}_{3}$ & $\mathrm{~L}_{1}$ & $\mathrm{~L}_{2}$ & $\mathrm{~L}_{3}$ \\
\hline \multicolumn{7}{|l|}{ (a) Unbaled hays } \\
\hline Organic matter & 873 & 887 & 890 & 889 & 878 & 885 \\
\hline Crude protein & 265 & 196 & 198 & 237 & 184 & 179 \\
\hline Neutral detergent fibre & 446 & 519 & 550 & 439 & 526 & 537 \\
\hline Acid detergent fibre & 309 & 319 & 340 & 330 & 375 & 396 \\
\hline Acid detergent lignin & 93 & 97 & 93 & 96 & 88 & 87 \\
\hline \multicolumn{7}{|l|}{ (b) Baled hays } \\
\hline Organic matter & 866 & 883 & 814 & 874 & 883 & 910 \\
\hline Crude protein & 230 & 197 & 150 & 193 & 156 & 158 \\
\hline Neutral detergent fibre & 510 & 493 & 530 & 473 & 522 & 548 \\
\hline Acid detergent fibre & 323 & 343 & 349 & 350 & 373 & 410 \\
\hline Acid detergent lignin & 87 & 99 & 97 & 101 & 93 & 91 \\
\hline $\mathrm{ADIN}^{2}$ & 7.4 & 7.7 & 14.0 & 8.4 & 13.1 & 8.4 \\
\hline Gross energy & 17.9 & 17.7 & 15.9 & 17.7 & 17.9 & 18.1 \\
\hline
\end{tabular}

${ }^{1} \mathrm{~L}_{1}, \mathrm{~L}_{2}, \mathrm{~L}_{3}$ are harvesting stages (see Tab. I).

2 Acid detergent insoluble $\mathrm{N}$ : \% of total $\mathrm{N}$.

of the leaf, stem and grain. For both types of hays, CP concentration decreased in all botanical fractions as seed maturation progressed, while NDF concentration increased in the vegetative structures but decreased in the grains. A similar trend was observed for ADL concentration. The variation of $\mathrm{NDF}$ and ADL concentrations in hairy vetch stems was, however, very limited, while in common vetch stems the ADL increase was very important (more than $70 \%$ between $\mathrm{L}_{1}$ and $\mathrm{L}_{3}$ ).

Baled hay samples, with the exception of $\mathrm{L}_{2}$ common vetch, had lower $\mathrm{CP}$ concentrations than hay forage collected prior to baling. Conversely, the NDF and ADF concentrations from baled samples had higher values than those observed from unbaled samples. The OM concentrations were similar in baled and unbaled hays, except for the baled common vetch hay at the $\mathrm{L}_{3}$ stage, which showed a low OM content (814 g. $\left.\mathrm{kg}^{-1} \mathrm{DM}\right)$.

\subsection{Digestibility of nutrients and DM intake}

Digestibility of nutrients for common vetch hay decreased between $\mathrm{L}_{1}$ and $\mathrm{L}_{2}$ but the reduction was only significant for NDF. From $\mathrm{L}_{2}$ to $\mathrm{L}_{3}$, however, digestibility of all nutrient fractions decreased significantly. Within hairy vetch hay samples, a trend towards a lower nutrient digestibility was observed between $\mathrm{L}_{1}$ and $\mathrm{L}_{2}$. From $\mathrm{L}_{2}$ to $\mathrm{L}_{3}$, however, the opposite trend was true. Thus, digestibility values at $\mathrm{L}_{3}$ were close to those observed for $\mathrm{L}_{1}$ (Tab. III). The species effect did not show a clear trend. For the $\mathrm{L}_{1}$ and $\mathrm{L}_{2}$ harvesting stages, common vetch showed higher digestibility values than hairy vetch, with significant differences for NDF and ADF in the $\mathrm{L}_{1}$ stage and for all fractions in the $\mathrm{L}_{2}$ stage. On the contrary, hairy vetch showed higher digestibility values at the $\mathrm{L}_{3}$ stage, but differences were only significant for OM and ADF. Voluntary DM intake of common vetch and hairy vetch 

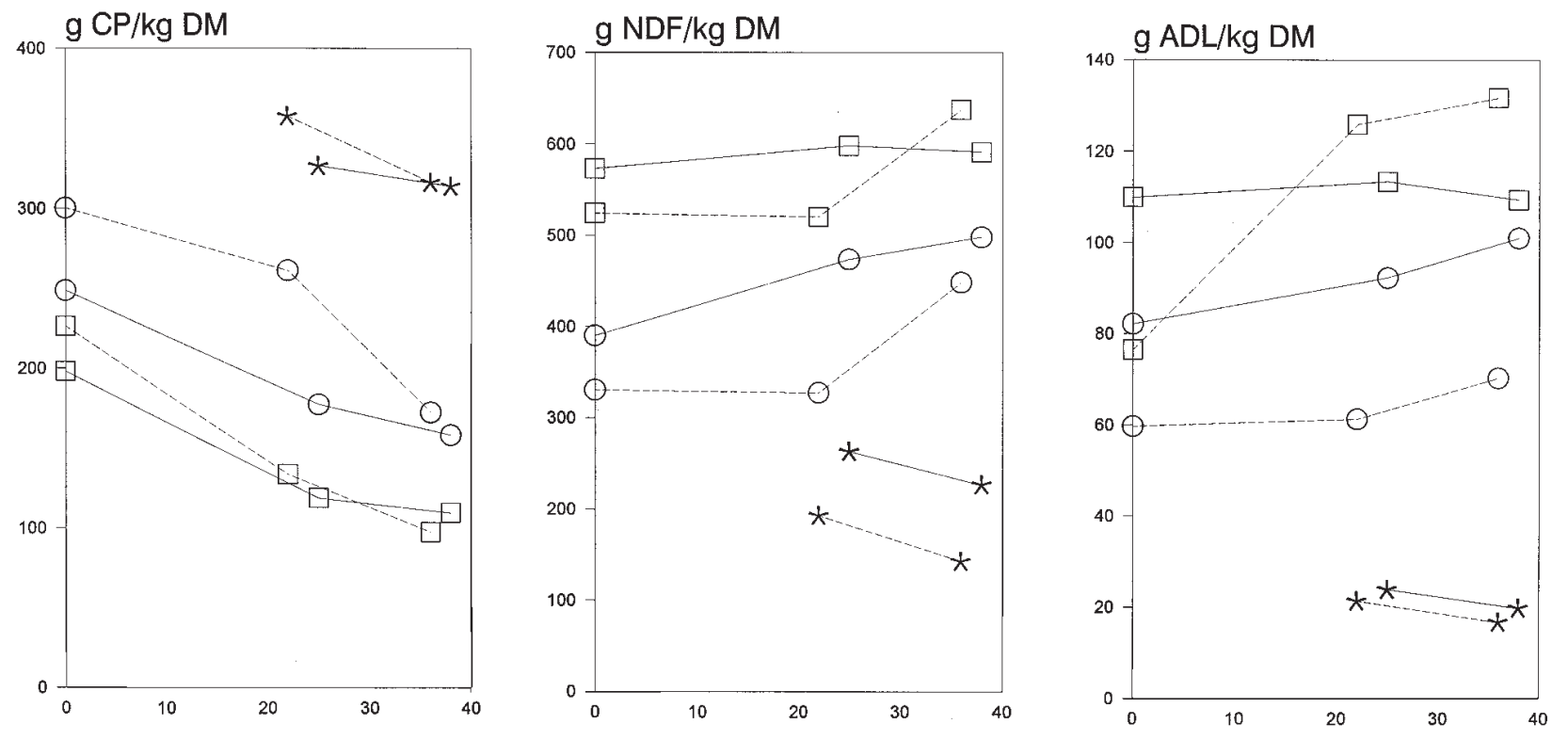

Figure 1. Effects of maturity on the concentration of crude protein (CP), neutral detergent fibre (NDF), and acid detergent lignin (ADL) of leafs $(\bigcirc)$, stems $(\square)$ and grains $(*)$ of unbaled hays of common vetch $(---)$ and hairy vetch $(-)$. 
Table III. Voluntary dry matter intake $\left(\mathrm{g} \cdot \mathrm{kg}^{-0.75} \cdot \mathrm{d}^{-1}\right)$ and nutrient digestibility $(\%)$ of baled hays from common vetch and hairy vetch at three harvest stages.

\begin{tabular}{|c|c|c|c|c|c|c|c|c|c|c|c|}
\hline \multirow{3}{*}{ Item } & \multicolumn{8}{|c|}{ Harvest stage effects ${ }^{1}$} & \multirow{2}{*}{\multicolumn{3}{|c|}{$\begin{array}{c}\text { Species effects } \\
(P \text {-value })\end{array}$}} \\
\hline & \multicolumn{4}{|c|}{ Common vetch } & \multicolumn{4}{|c|}{ Hairy vetch } & & & \\
\hline & $\mathrm{L}_{1}$ & $\mathrm{~L}_{2}$ & $\mathrm{~L}_{3}$ & SEM & $\mathrm{L}_{1}$ & $\mathrm{~L}_{2}$ & $\mathrm{~L}_{3}$ & SEM & $\mathrm{L}_{1}$ & $\mathrm{~L}_{2}$ & $\mathrm{~L}_{3}$ \\
\hline DM intake & 44.7 & 55.5 & 54.4 & 2.28 & 50.6 & 56.5 & 62.9 & 3.78 & 0.570 & 0.877 & 0.363 \\
\hline \multicolumn{12}{|c|}{ Apparent digestibility: } \\
\hline OM & $67.8^{\mathrm{a}}$ & $66.3^{\mathrm{a}}$ & $59.1^{\mathrm{b}}$ & 0.95 & 63.5 & 56.9 & 61.6 & 1.43 & 0.106 & 0.006 & 0.027 \\
\hline Energy & $65.3^{\mathrm{a}}$ & $63.1^{\mathrm{a}}$ & $56.0^{\mathrm{b}}$ & 0.79 & 60.3 & 54.6 & 58.8 & 1.54 & 0.089 & 0.007 & 0.057 \\
\hline $\mathrm{CP}$ & $76.7^{\mathrm{a}}$ & $76.4^{\mathrm{a}}$ & $68.8^{\mathrm{b}}$ & 0.84 & $76.1^{\mathrm{a}}$ & $66.3^{\mathrm{b}}$ & $71.6^{\mathrm{c}}$ & 0.86 & 0.340 & $<0.001$ & 0.082 \\
\hline $\mathrm{NDF}$ & $64.5^{\mathrm{a}}$ & $53.7^{\mathrm{b}}$ & $48.7^{\mathrm{c}}$ & 1.09 & 47.6 & 44.5 & 48.6 & 1.83 & 0.002 & 0.025 & 0.944 \\
\hline $\mathrm{ADF}$ & $57.4^{\mathrm{a}}$ & $52.0^{\mathrm{a}}$ & $46.1^{\mathrm{b}}$ & 1.49 & 48.9 & 42.8 & 50.2 & 1.35 & 0.066 & 0.010 & 0.052 \\
\hline
\end{tabular}

$\mathrm{OM}=$ organic matter; $\mathrm{CP}=$ crude protein; $\mathrm{NDF}=$ neutral detergent fibre; $\mathrm{ADF}=$ acid detergent fibre. $\mathrm{SEM}=$ standard error of the mean.

${ }^{\mathrm{a}-\mathrm{c}}$ Means between harvest stages within species with different superscripts are significantly different $(P<0.05)$.

${ }^{1} \mathrm{~L}_{1}, \mathrm{~L}_{2}$, and $\mathrm{L}_{3}$ are harvesting stages (see Tab. I). 
hays (Tab. III) was unaffected by the species or harvest stage effects.

\subsection{Ruminal degradation of DM and CP}

Most kinetic estimates of DM rumen degradation were affected by the harvesting stage except the degradation rate of DM $\left(\mathrm{k}_{\mathrm{d}}\right)$ from common vetch hay. The same trend was observed regarding the species effect. In this case, only the soluble DM fraction at the $\mathrm{L}_{3}$ stage was not significant.

The changes in DM degradability were similar to those observed for digestibility. For common vetch, DM degradability declined through the seed filling period, but mainly between $L_{2}$ and $L_{3}$. For hairy vetch, however, degradability decreased between $\mathrm{L}_{1}$ and $\mathrm{L}_{2}$ and increased during the $\mathrm{L}_{2}-\mathrm{L}_{3}$ period. The greatest differences between both hays were found, therefore, at the $\mathrm{L}_{2}$ stage. The changes of DM degradability were opposite to those of the undegradable fraction, whose values were higher in the hairy vetch hay, except for the $\mathrm{L}_{3}$ stage.

Rumen degradation kinetic estimates of $\mathrm{CP}$ were affected by the harvesting stage (Tab. IV). The CP undegrable fraction from common vetch hays increased from $8 \%$ at the $\mathrm{L}_{1}$ to $26.6 \%$ at the $\mathrm{L}_{3}$ stage. Nevertheless, the rate of change (\% unit. $\left.\mathrm{d}^{-1}\right)$ was three times higher in the $\mathrm{L}_{2}-\mathrm{L}_{3}$ period (0.89) than in the $\mathrm{L}_{1}-\mathrm{L}_{2}$ period (0.28). As a consequence, the soluble and potentially degradable fractions of common vetch hays decreased from $\mathrm{L}_{1}$ to $\mathrm{L}_{3}$. The $\mathrm{CP}$ undegradable fraction from hairy vetch hays, however, reached its maximum $(25.5 \%)$ at the $\mathrm{L}_{2}$ stage. The rate of increase observed for this fraction between the $\mathrm{L}_{1}$ and $\mathrm{L}_{2}$ stages (0.52) was lower than the rate of decrease between the $\mathrm{L}_{2}$ and $\mathrm{L}_{3}$ stages $(0.70)$. As a result, $\mathrm{CP}$ degradability from common vetch decreased over the seed filling period, but only the value at the $L_{3}$ stage was significantly different. For hairy vetch, significant differences were found between the three harvesting stages, with the lowest value at the $\mathrm{L}_{2}$ stage.

\section{DISCUSSION}

There was a greater $\mathrm{CP}$ concentration for common vetch than for hairy vetch hays, which was in agreement with the higher leaf to stem ratio at flowering and a higher harvest index during pod-filling (Tab. I). Treviño and Caballero [21] and Caballero et al. [7] also indicated higher leaf to stem ratio and seed weight in common vetch than in hairy vetch, respectively. In our work, the depletion of CP concentration $(13.8 \%$ on average) observed between unbaled and baled hays was probably due to relatively higher losses of protein-rich plant parts, such as leafs and grains (Fig. 1), during baling.

Crude protein concentration decreased as seed maturing progressed. The rate of change, however, was much higher in the $\mathrm{L}_{1}-\mathrm{L}_{2}$ than in the $\mathrm{L}_{2}-\mathrm{L}_{3}$ phase, suggesting an offsetting effect between a decreasing $\mathrm{CP}$ concentration of vegetative structures and an increasing proportion of the proteinrich grain. Caballero et al. [8] illustrated the same effect when comparing fresh forage yield and forage $\mathrm{CP}$ concentration of common vetch at four maturing stages during pod-filling and indicated that maximum $\mathrm{CP}$ yields per ha were reached when there was $50 \%$ DM in the seed. In the present work, however, this offsetting effect was not observed in baled common vetch samples, which showed a high decrease of CP concentration in the $\mathrm{L}_{2}-\mathrm{L}_{3}$ phase. This may have been the result of a higher loss of seed from maturing pods in common vetch than in hairy vetch when both species were baled at the most advanced seed maturing stage. These losses may be caused by the dehiscent character of pods and the high seed weight of common vetch. The $\mathrm{L}_{3}$ common vetch hay could have been affected by soil contamination during mechanical baling. Therefore, both effects (grain loss and soil contamination) may explain the higher rate 
Table IV. Degradation characteristics of dry matter and crude protein of baled hays from common vetch and hairy vetch at three harvest stages.

\begin{tabular}{|c|c|c|c|c|c|c|c|c|c|c|c|}
\hline \multirow{3}{*}{ Item } & \multicolumn{8}{|c|}{ Harvest stage effects ${ }^{1}$} & \multirow{2}{*}{\multicolumn{3}{|c|}{$\begin{array}{c}\text { Species effects } \\
(P \text {-value })\end{array}$}} \\
\hline & \multicolumn{4}{|c|}{ Common vetch } & \multicolumn{4}{|c|}{ Hairy vetch } & & & \\
\hline & $\mathrm{L}_{1}$ & $\mathrm{~L}_{2}$ & $\mathrm{~L}_{3}$ & SEM & $\mathrm{L}_{1}$ & $\mathrm{~L}_{2}$ & $\mathrm{~L}_{3}$ & SEM & $\mathrm{L}_{1}$ & $\mathrm{~L}_{2}$ & $\mathrm{~L}_{3}$ \\
\hline \multicolumn{12}{|l|}{ Dry matter } \\
\hline $\mathrm{A}(\%)$ & $24.5^{\mathrm{a}}$ & $26.5^{\mathrm{b}}$ & $22.2^{\mathrm{c}}$ & 0.27 & $35.0^{\mathrm{a}}$ & $22.2^{\mathrm{b}}$ & $22.6^{\mathrm{b}}$ & 0.43 & $<0.001$ & $<0.001$ & 0.524 \\
\hline $\mathrm{B}(\%)$ & $53.8^{\mathrm{a}}$ & $45.3^{\mathrm{b}}$ & $38.9^{c}$ & 0.41 & $38.0^{\mathrm{a}}$ & $36.9^{\mathrm{b}}$ & $41.4^{\mathrm{c}}$ & 0.37 & 0.003 & 0.006 & 0.045 \\
\hline $\mathrm{U}(\%)$ & $21.7^{\mathrm{a}}$ & $28.2^{\mathrm{b}}$ & $38.9^{\mathrm{c}}$ & 0.24 & $27.0^{\mathrm{a}}$ & $41.8^{\mathrm{b}}$ & $36.0^{\mathrm{c}}$ & 0.21 & 0.020 & 0.007 & 0.030 \\
\hline $\mathrm{K}_{\mathrm{d}}\left(\% \cdot \mathrm{h}^{-1}\right)$ & 7.7 & 8.4 & 9.1 & 0.59 & $9.0^{\mathrm{a}}$ & $9.3^{\mathrm{a}}$ & $7.1^{\mathrm{b}}$ & 0.38 & 0.035 & 0.012 & 0.005 \\
\hline $\mathrm{D}(\%)$ & $63.6^{\mathrm{a}}$ & $60.2^{\mathrm{b}}$ & $51.6^{\mathrm{c}}$ & 0.59 & $63.7^{\mathrm{a}}$ & $49.7^{\mathrm{b}}$ & $52.0^{\mathrm{c}}$ & 0.43 & 0.779 & 0.004 & 0.600 \\
\hline \multicolumn{12}{|l|}{ Crude protein } \\
\hline $\mathrm{A}(\%)$ & $38.4^{\mathrm{a}}$ & $39.1^{\mathrm{a}}$ & $28.9^{\mathrm{b}}$ & 0.51 & $47.7^{\mathrm{a}}$ & $37.9^{\mathrm{b}}$ & $43.7^{\mathrm{c}}$ & 0.56 & $<0.001$ & 0.423 & 0.006 \\
\hline $\mathrm{B}(\%)$ & $53.6^{\mathrm{a}}$ & $46.8^{b}$ & $44.5^{\mathrm{b}}$ & 0.97 & 39.8 & 36.6 & 39.9 & 0.97 & $<0.001$ & 0.079 & 0.038 \\
\hline $\mathrm{U}(\%)$ & $8.0^{\mathrm{a}}$ & $14.1^{\mathrm{b}}$ & $26.6^{c}$ & 0.56 & $12.5^{\mathrm{a}}$ & $25.5^{\mathrm{b}}$ & $16.4^{\mathrm{c}}$ & 0.38 & 0.005 & 0.024 & 0.001 \\
\hline $\mathrm{K}_{d}\left(\% \cdot \mathrm{h}^{-1}\right)$ & $8.4^{\mathrm{a}}$ & $11.6^{\mathrm{ab}}$ & $12.7^{\mathrm{b}}$ & 0.88 & 12.3 & 14.0 & 10.0 & 1.47 & 0.020 & 0.474 & 0.095 \\
\hline $\mathrm{D}(\%)$ & $78.3^{\mathrm{a}}$ & $76.6^{\mathrm{a}}$ & $65.1^{\mathrm{b}}$ & 0.61 & $79.8^{\mathrm{a}}$ & $67.7^{\mathrm{b}}$ & $74.5^{\mathrm{c}}$ & 0.73 & 0.038 & 0.004 & 0.009 \\
\hline
\end{tabular}

A, B, and $U$ represent soluble, non soluble degradable, and undegradable fractions, respectively. $K_{d}$, fractional degradation rate of fraction B. D, degradability (calculated for a rumen transit rate of $\left.2.91 \pm 0.32 \% \cdot \mathrm{h}^{-1}\right)$. SEM $=$ standard error of the mean.

${ }^{\mathrm{a}-\mathrm{c}}$ Means between harvest stages within species with different superscripts are significant $(P<0.05)$

${ }^{1} \mathrm{~L}_{1} \mathrm{~L}_{2}$, and $\mathrm{L}_{3}$ are harvesting stages (see Tab. I). 
of decrease of the CP concentration from baled common vetch samples between $\mathrm{L}_{2}$ and $\mathrm{L}_{3}$, although the individual incidence of each factor cannot be elucidated. Most fibre fractions showed an increasing trend from $\mathrm{L}_{1}$ to $\mathrm{L}_{3}$ (Tab. II) which suggests that, for these fractions, the increasing proportion of grain does not fully compensate the effects of maturity on vegetative structures.

Digestibility results of baled hays showed a general agreement with both the evolution of their chemical composition and the quantity of the DM undegradable fraction. Since stems are the less digestible part of the plant, the high increase in ADL concentration for common vetch stems (Fig. 1) should be related to the observed reduction of digestibility. Conversely, ADL was fairly constant in the stems of hairy vetch. In addition, the grain compensatory effect was apparent at the $\mathrm{L}_{3}$ stage in hairy vetch but not in common vetch. Here, the grain effect was obscured by an unexpected high nonstructural silica concentration in this hay, which may have produced an additional depression of feed digestibility [23].

The changes of DM degradability with maturity showed, in both hays, a trend similar to that observed for the apparent digestibility of OM or energy, since the main part of forage digestion occurs in the rumen. Few studies have reported the DM degradability of vetch hay samples. Rubio [18] found a mean value of $68.6 \%$ from a common vetch hay harvested at the flowering stage. This sample, however, had a lower NDF, ADF, and ADL concentration than the $\mathrm{L}_{1}$ samples of this study.

The different evolutions of digestibility or degradability with maturity in common vetch and in hairy vetch are explained considering that (1) maturity effects are the result of the digestibility depression in vegetative structures (due to increases in cell wall and lignin) and of the enlargement of the proportion of grains (of low cell wall content), and that (2) both effects are different for both species. So, in common vetch the progression of maturity seems to be more intensive and the grain compensatory effect less important (in baled hays) than in hairy vetch. The present results suggest that if higher quality forage is the objective, vetch forage should be harvested at the bloom stage and that common vetch is preferable due to its greater nutrient supply. Nevertheless, if maximum export of nutrients is the objective, the most interesting option seems to be the use of hairy vetch harvested with mature legumes, because the hay collected maintains an energy value similar to that observed at the bloom stage without an important decrease in the protein nutritional value. In addition, as a consequence of the delay in the cutting date, this option has the advantages of a lower rain hazard and faster and easier haymaking. Another possible alternative for this purpose would be the use of recently released non-shattering common vetch cultivars at later harvesting stages.

Ruminal degradability of CP of the common vetch hay studied by Rubio [18] was the same $(78.3 \%)$ as that observed in the present study for the $\mathrm{L}_{1}$ stage. Degradability of $\mathrm{CP}$ decreased from flowering to the podfilling harvesting stages. Andres [3] reported a value of $75 \%$ for the grain CP degradability of the two vetch species, which is similar to those observed in our study for grain-free samples from the $\mathrm{L}_{1}$ stage. Therefore, grain maturation may have produced an offsetting effect on $\mathrm{CP}$ degradability through maturation. As in the other parameters (CP concentration, digestibility or DM degradability), this compensatory grain effect was observed for hairy vetch but not for common vetch hays. Decreases of CP degradability were mostly related to increasing proportions of both the rumen undegradable CP and the ADIN fractions of the hays. Therefore, these lower values cannot be considered as a positive effect.

If $\mathrm{k}_{\mathrm{p}}$ proposed by the PDI system [24] $\left(6 \% \cdot \mathrm{h}^{-1}\right)$ had been used instead of the calculated values, rumen $\mathrm{CP}$ degradability values of $69.7,69.9$ and $59.1 \%$ for $\mathrm{L}_{1}, \mathrm{~L}_{2}$ and 
$\mathrm{L}_{3}$ for common vetch hay would have been obtained, respectively. Corresponding values for hairy vetch hay would have been $74.4,63.5$ and $68.6 \%$, respectively.

On the contrary, degradabilities of $\mathrm{CP}$ presented in Table IV are apparent since microbial contamination was not taken into account. The application of a corrective equation, obtained under similar experimental conditions by Rodriguez et al. [17] produced values of $82.9,81.7$, and $70.9 \%$ and $84.9,73.9$, and $81.2 \%$ at the $\mathrm{L}_{1}, \mathrm{~L}_{2}$ and $\mathrm{L}_{3}$ stages for common vetch and hairy vetch hays, respectively. The underestimation of $\mathrm{CP}$ degradability derived from microbial contamination increased with the maturity stage. Nevertheless this variation was low in both hays. Since the rumen undegradable protein fraction should also be indigestible in the small intestine, the high degradability of these hays is indicative of a low content of digestible bypass protein. Therefore, as previously observed for vetch-oat hays [11], nitrogen use efficiency in vetch hays is mainly linked to microbial protein yield.

In conclusion, although CP concentration decreased and NDF increased as plant maturing progressed within the pod-filling phase of the two species, the effects of maturity on the depletion of the nutrients supply were more pronounced for common vetch than for hairy vetch hays. Consequently, when the production objective is quality hays, the best option is common vetch harvested at bloom. Conversely, when the maximum export of nutrients is the objective, the use of hairy vetch harvested at the stage of mature legumes is the most interesting option.

\section{ACKNOWLEDGMENTS}

This work was supported by European Union funds of CAMAR and FAIR Programmes (Contracts No. CT 90-0002 and 96-1893, respectively).

\section{REFERENCES}

[1] Alibes X., Tisserand J.L., Tables of the nutritive value for ruminants of Mediterranean forages and by-products, Options Mediterranéennes, Serie B: Études et Recherches, No. 4, Zaragoza, Spain, 1990.

[2] Alzueta C., Rebolé A., Barro C., Treviño J., Caballero $\mathrm{R}$., Changes in nitrogen and carbohydrate fractions associated with the field drying of vetch (Vicia sativa L.), Anim. Feed Sci. Technol. 52 (1995) 249-255.

[3] Andres S.G., Efecto de las características fisicoquímicas de los concentrados proteicos sobre la degradación ruminal de sus materias nitrogenadas, Ph.D. thesis, Universidad Politécnica de Madrid, Spain, 1990.

[4] AOAC, Official Methods of Analysis, 14th ed. Association of Official Analytical Chemits, Arlington, VA, 1984.

[5] Buxton D.R., Brasche M.R., Digestibility of structural carbohydrates in cool-season grass and legume forages, Crop Sci. 31 (1991) 1338-1345.

[6] Caballero R., An experts' survey on the role of legumes in arable cropping systems of the Mediterranean area, J. Sustainable Agric. 3 (1993) 133-154.

[7] Caballero R., Haj Ayed M., Gálvez J.F., Hernaiz P.J., Yield components and chemical composition of some annual legumes and oat under continental Mediterranean conditions, Agricultura Mediterranea 125 (1995) 222-230.

[8] Caballero R., Barro C., Rebolé A., Arauzo M., Hernaiz P.J., Yield components and forage quality of common vetch during pod filling, Agron. J. 88 (1996) 797-800.

[9] Caballero R., Rebolé A., Barro C., Alzueta C. Treviño J., García C., Farming practices and chemical bases for a proposed quality standard of vetch cereal hays, Field Crop Res. 47 (1996) 181-189.

[10] Droushiotis D.N., Mixtures of annual legumes and small-grained cereals for forage production under low rainfall, J. Agric. Sci. Camb. 113 (1989) 249-253.

[11] Haj Ayed M., Gonzalez J., Caballero R., Alvir M., Nutritive value of on-farm common vetchoat hays fed to sheep. II. Ruminal degradability, Ann. Zootech. (in press).

[12] Hintz R.W. Albretch K.A., Dry matter partitioning and forage nutritive value of soybean plant component, Agron. J. 86 (1994) 5-62.

[13] Moreira N., The effect of seed rate and nitrogen fertilizer on the yield and nutritive value of oat-vetch mixtures, J. Agric. Sci. (Camb.) 112 (1989) 57-66.

[14] Ørskov E.R., McDonald I., The estimation of protein degradability in the rumen from incubation measurements weighed according to rate of passage, J. Agric. Sci. (Camb.) 92 (1979) 499-503. 
[15] Roberts C.A., Moore K.J., Johnson K.D., Forage quality and yield of wheat-vetch at different states of maturity and vetch seeding rales, Agron. J. 81 (1989) 57-60.

[16] Robertson J.B., Van Soest P.J., The detergent system of analysis and its application to human foods, in: James W.P.T., Theander O. (Eds.), The Analysis of Dietary Fiber in Foods, Marcel Dekker, New York, 1981, pp. 123-158.

[17] Rodríguez C.A., González J., Alvir M.R., Cajarville C., Underestimation of in situ effective degradability of $\mathrm{N}$ due to microbial contamination, in: VIIIth International Symposium on Protein Metabolism and Nutrition, Aberdeen, United Kingdon, 1999, p. 67.

[18] Rubio A.J., Influencia de la relación veza-avena sobre la utilización ruminal de estos henos en corderos, Master Science thesis, Instituto Agronómico Mediterráneo, Zaragoza, Spain, 1994.

[19] Sanderson M.A., Hornstein J.S., Wedin W.F. Alfalfa morpholicial state and its relation to in situ digestibility of detergent fiber fractions of stems, Crop Sci. 29 (1989) 1315-1319.

[20] SAS, SAS/STAT User's Guide, Statistical Analysis Systems Institute Inc., North Carolina, 1990, pp. 1135-1194

[21] Treviño J., Caballero R., Estudio comparado de los rendimientos, composición químico-bromatológica y digestibilidad de las especies Vicia sativa L. y Vicia villosa Roth, Pastos 3 (1973) 248-257.

[22] Treviño J., Caballero R., Gil F.J., Estudio comparado de la composición química, digestibilidad y valor energético de diferentes cultivares y poblaciones de veza, Pastos 9 (1979) 140-149.

[23] Van Soest P.J., Jones L.H.P., Effect of silica in forage upon digestibility, J. Dairy Sci. 51 (1968) 1644-1648.

[24] Vérité R., Michalet-Doreau B., Chapoutot P., Peyraud J.L., Poncet C., Révision du système des protéines digestibles dans l'intestin (PDI) Bull. Tech. CRZV Theix INRA 70 (1987) 19-34. 